\title{
THE IMPLEMENTATION OF DUOLINGO TO TEACH DESCRIPTIVE TEXT IN SCIENTIFIC APPROACH
}

\author{
Dyah Ayu Puspita Sarie', Anita Anggraeni² \\ ${ }^{1}$ IKIP Siliwangi \\ ${ }^{2}$ IKIP Siliwangi \\ ${ }^{1}$ dyah_sarie@student.ikipsiliwangi.ac.id,,2ªnitaenglish26@gmail.com
}

\begin{abstract}
Reading is a process of communication. The process of reading can be stated through direct communication or by writing as well imagination of the reader that can be expressed in daily activities. This article discussed how to apply the Duolingo application using techniques that apply a scientific approach method in teaching reading process. The subject of this research consist of 38 students. The aim of this article was to find out the extent of the students understanding in reading seeing the right words and readings that are in the application. Descriptive qualitative was used in this research. Based on the result, Duolingo application that applied in learning descriptive text can help the students in learning process.
\end{abstract}

Keywords: Duolingo, Reading, Descriptive Text, Scientific Approach

\section{INTRODUCTION}

In the community, Richard and Schmidt (2010:206) cited in (Panti, Al, Di, \& Ngajum, 2019) foreign language is " A language which is not the Native Language of large number of people in a particular country or region, is not used as a medium of instruction in school, and is not widely used a medium of communication in government,media,etc. Foreign language are now widely used for learning materials both for reading,or communicating among people. English is a foreign language that is considered important for the community because of it's widespread use and is certainly used if you want to apply for a job. English also has a strategic place, in addition to communication it can also relate between nations.

Reading is a process of communication between the reader and the media being read, the process of reading can be stated through direct communication or by writing the meanings that are made in reading are in excess of the meanings that arise from the interpretation of written language (Lorange, 2014:30) as cited in (Parmawati,2018)

Descriprive is a type of research that describes object, places, or living things. Generally this text describes the nature, characteristics, and shape. "Descriptive is a text which says a thing clearly and neatly so the rather knows the aim of the contents of the text, because writing involves the sense, such as hearing, seeing, feeling, tasting, and touching". Pratiwi and Rahmahsari in Puspitaloka (2016:152) as cited in (Hasibuan, 2019).

The use the app duolingo, learners can install the application to learn it from Playstore, Android and IOS devise. This application is also equipped with 16 languages from various countries and various countries and vaarious teaching techniques. With the aissted learning based on mobile learning, it can help further material related to the second language of teaching and learning. ( Pachler, Bachmair \& Cook, 2010) as cited in (Nushi,2019). 
A scientific approach is a way that is designed so that students can more easily understand and solve their own problems. This is based on the essence of learning which is actually a scientific process carried out by students and teachers. Based on results through science, the information obtained must be related to the experiment and the results analyzed (Longman, 2014) as cited in (Zaim, 2017).

\section{LITERATURE REVIEW}

\section{Definition of Reading}

Reading is a skill that is person and related to writing and speaking. Reading this skill most important than speaking and writing as reading is not only a source of information and pleasant activity but also a method of consolidating and extending one's language knowledge (Patel, 2008) as cited in (Andini, 2019).

\section{Skill of Reading}

The following are skills of reading about the descriptive text, among others, as follows :

1. Activating

Students use their experience to be able to understand the text and the few abilities they have. And obtained through this activity. (example: text descriptive)

2. Summarizing

In terms of summarizing, students are emphasized to make meaningful summaries of sentences or words they read. (example: conclusion from the text)

3. Monitoring and Clarifying

Teacher determine if they understand the text. If they don't understand then the teacher will explain the topic from the reading that is not yet understood. (example: text descriptive)

4. Visualizing and Organizing

Under this technique, students are taught to learn through pictures and text, and how strudents can describe the picture. (example: picture of figure)

5. Searching and Selecting

Students find out about the material provide and the students must also be able to select out which ones should be taken and which should not be taken by these students (example: describe, explaining, and search)

6. Questioning

Students are allowed to ask the teacher about things that are not understood from the material that has been sought by the students. (example : question-answer relationship)

7. Conclusion

Students give conclusions with the text they have learned briefly and not too long. (example: conclusion about the reading)

\section{METHOD}

In this study, researcher used qualitative research method. Qualitative descriptive tends to data analysis, the process of describing it more with definition and meaning. Qualitative descriptive is included in qualitative research, emphasizing the description of the sentences being analyzed. Theoretically through a research approach (Sandelowski, as cited in (Lambert \& Lambert, 2012)) as cited in (Nurmalasari \& Apsari 2019).

The population of this research is the seventh grade students of SMPN in Cimahi, they are 444 students of seventh classes. In this research class devide into one group as descriptive qualitative. As the sample of the research are class VII I with 38 students. 
To collect the data this research uses the pre test, post test, quistionnare, and interview. The first steps is pre test, pre test is where a is tested on a (statistically) small sample of respondents before a full scale study, in order to identify any problems such as unclear wording. The second steps is questionnaire, quistionnare is an information gathering technique that allow analysts to learn the attitudes, beliefs, behaviors, and characteristics of several key people. Then the third is questionnaire and the last interview.

The researchers as two tests (reading test) pre test and post test. The first is done by giving a worksheet about descriptive text. And the second test isin the form of a worksheet whose contents are about the application material. In this method the explanation must be concise, but must be complete information that is examined experimentally must be qualified by the reader. The new methods found can be explained in detail or in full. Cite previously published procedures in References.

\section{RESULTS AND DISCUSSION}

\section{Results}

The research consist of four meeting in with an allocation of time for each meeting $2 \times 45$ minutes ( two hours of study). The result of each will be arranged on four stages of descriptive qualitative, namely: (1) pre test, (2) quistionnare, (3) post test, (4) interview.

Step 1. On pre test stage, the first steps at this stage in the researcher gives a preliminary test in the form of multiple choice questions totalling 10 number with a print out which is then filled out by students by selecting one of the answers that is considered correct to find out the student's ability in the material to be taken by the researcher.

Step 2. On quistionnare stage, the second steps after conducting the pre test, students fill out a worksheet that contains learning methods used by researchers. Does the student like the method or not and give their reasons through interviews.

Step 3. On post test stage, the third steps the final evaluation test is how the development of students' knowledge after using the methods taken and their abilities after learning it. Usually the results look better than the beginner's test.

Step 4. On interview stage, the four steps after doing various stages, here is the final step in one of the series, namely by the interviewing students in the class, referring to the results of the questionnaire they have filled out. Here the researcher as the right to ask any questions related to material that has been given.

\begin{tabular}{cll}
\hline \multicolumn{1}{c}{ Acting } & \multicolumn{1}{c}{ Observing } \\
\hline Meeting & \multicolumn{1}{c}{ Topic } & \multicolumn{1}{c}{ Activity } \\
\hline 1 & Pre-test & $\begin{array}{l}\text { In the first meeting, the researcher gave the students 10 number of } \\
\text { multiple choice about descriptive text. }\end{array}$ \\
\hline 2 & Quistionnare & $\begin{array}{l}\text { The student fill in a number of questions in the form of statement } \\
\text { related to wheather they like or dislike the method given. }\end{array}$ \\
\hline 3 & Post-test & $\begin{array}{l}\text { In the last meeting, the researcher back to give a test in the form } \\
\text { of multiple choice of 10 numbers to be filled by students related } \\
\text { to learning that has been given. }\end{array}$ \\
\hline
\end{tabular}




\begin{tabular}{ll}
\hline 4 Interview & $\begin{array}{l}\text { The step is given after the quistionnare and post test are carried } \\
\text { out. Researchers first asses the results that students have done in } \\
\text { the previous } 3 \text { steps. After that we choose from several students to } \\
\text { be interviewed. }\end{array}$ \\
\hline
\end{tabular}

Researcher divided students in classes into eight group, and the following is a description of the results of several groups:

\section{First Group}

They were very enthusiastic to accept the application given by the teacher. Under the evidence they ask what they don't know.

2. Second Group

In group two, they are somewhat confused by giving method because before they did not know this method. So they don't do well.

3. Third Group

In group three, there aresome students who understand and some more the method provided makes students less understanding what is learned, the way to anticipate it is by of them tells about the method to students who do not understand.

4. Four Group

They understand very well with the method given, because from the group before it, there was someone who had used the method at this time.

5. Five Group

Very like of this method, some even download with the method provided during the learning process.

6. Six Group

In this group, they don't seem to understand the method learned. This is exactly the same as group two.

7. Seven Group

They are rather difficult to access the methods learned with the adequate internet constraints and lack of monitoring.

8. Eight Group

Eight group, they understand and record things that they think are important to understand when they memorize them.

\section{Discussion}

Data obtained from interviews, respondents stated that such an approach could improve to duolingo descriptive text in reading class. This can be supported by one observation class.

With the discussion obtained is as follows:

To be a meeting, students still seem to be less active the learning process. But at a later meeting it was seen that some students who began to be active and had a great knowledge of what was taught by the teacher. Students must come in less active are assisted by peers to understand learning that is not understood. Students are initially taught with descriptive paragraphs and sentences and they fill in the answers from the questions given. Even though they don't understand students still pay attention to the material that the teacher gives to their students. They also asked related material, such as descriptive types of the benefits of descriptive text what are the linguistic features contained in descriptive text. Although there are still many students to be less active, the learning process is still going well. 
In the second meeting, students have started to be active compared to the initial meeting. Students are more interactive with the material in classroom and are very enthusiastic about what is there, they also have different opinions that can give the impression of being very active to learn in the class. For example, they can determine the wrong thing by saying :

A. : "I have a rabbit. His fur is white and has black spots. He has quite long ears and a short tail. He cute red big eyes!"

Sometimes, if students find vocabulary like the sentences above they will teacher ask the bales or close friends. Even though they are confused, this is a challenge for students to be able to solve problems. At that time they were required to make notes in their books. This means they can re-read which is owned written and can be understood, especially in reading. And this meeting can be better than the first meeting.

In the last meeting, students participate in this activity. Because in the 2013 curriculum they are required to work in groups before they have already sat in groups so it is not difficult and can share it. Students also follow the instructions given the teacher by carring tools such as laptops. Each group was instructed to bring a laptop from to home to use at school. In this final lesson students give questions to look for the learning media duolingo, then each group reads sentences in the media. They are very interactive, responsive, and like the media provided. They were quick to ask questions that they thought were quite difficult, but before this learning was done students had previously known the Duolingo application and had been applied at a certain time.

From observations taken by researchers, it can be concluded that the research taken proves that its use is effective for $7^{\text {th }}$ grade first school level students. This theory is supported from (Arun, \& Mohit, 2016) as cited in (Arista et al, 2018) "the Computer based learning that could be used by the teachers takes the form of smartphone based stimulation technology".

\section{CONCLUSION}

The uses of Duolingo descriptive text method is can effectively help them in classroom learning especially reading. They really like the methods provided with the varied learning models and don't make students bored learning approaches process. Giving methods can be activating, summarizing, monitoring and clarifying, visualizing and organizing, searching and selecting, questioning, and conclusion.

\section{ACKNOWLEDGMENTS}

The researchers want to give happiness special gratitude to those who has given their help, guidance, correction, comments, suggestions, and support that greatly improved this article.

\section{REFERENCES}

Arista, F. S., Education, P., Program, P., Kuswanto, H., Education, P., \& Program, P. (2018). Virtual Physics Laboratory Application Based on the Android Smartphone to Improve Learning Independence and Conceptual Understanding. 11(1), 1-16.

Eqbali, M. H. (2003). Duolingo : A Mobile Application to Assist Second Language Learning ( App Review ). 17(1), 89-98.

Hasibuan, A., \& Irmayana, A. (2019). The Effect of Using Think Pair Share ( Tps ) Model on Students ' In Writing Descriptive Text Ability ( A Study At The Tenth Grade Students of Sma Negeri 1 Pinangsori 2018 / 2019 Academic Year ). 2(1), 57-70. 
Nurmalasari, M., \& Apsari, Y. (2019). Improving Students 'Participation in Speaking. 2(2), 14-20.

Panti, P., Al, A., Di, M., \& Ngajum, D. (2019). Pembelajaran Bahasa Inggris Melalui Media Game Pada Panti Asuhan Al Maun Di Desa Ngajum. (September).

Siliwangi, I. (2014). The Study Correlation Between Reading Habit and Pronunciation Ability At The Second Grade Students. 1-7.

Zaim, M. (2017). Implementing Scientific Approach to Teach English at Senior High School In Indonesia. 13(2), 33-40. Https://Doi.Org/10.5539/Ass.V13n2p33 